\title{
SOME SIMPSON TYPE FRACTIONAL INTEGRAL INEQUALITIES FOR FUNCTIONS OF BOUNDED VARIATION
}

\author{
Mohamed Doubbi Bounoua and Chuntao Yin
}

Abstract. In this paper, we focus on the Simpson type fractional integral inequalities. The approximate schemes of these integral inequalities are derived as well.

Mathematics subject classification (2020): 26A33, 26D10, 41A55.

Keywords and phrases: Riemann-Liouville fractional integral, Hadamard fractional integral, fractional integral inequality, Simpson type inequality.

\section{REFERENCES}

[1] T. M. Apostol, Mathematical Analysis, Second Edition, Addision-Wesley Publishing Company, Boston, USA, 1975.

[2] L. P. Chen, Y. G. HE, Y. Chai AND R. C. WU, New results on stability and stabilization of a class of nonlinear fractional-order systems, Nonlinear Dyn. 75, 4 (2014), 633-641.

[3] D. Cruz-URible And C. J. Neugebauer, Sharp error bounds for the trapezoidal rule and Simpson's rule, J. Inequal. Pure Appl. Math. 3, 4 (2002), 1-22.

[4] V. ČulJak, J. PeČArić AND L. E. Persson, A note on Simpson's type numerical integration, Soochow J. Math. 29, 2 (2003), 191-200.

[5] S. S. Dragomir, On Simpson's quadrature formula for Lipschitzian mappings and applications, Soochow J. Math. 25, 2 (1999), 175-180.

[6] S. S. Dragomir, On Simpson's quadrature formula for mappings of bounded variation and applications, Tamkang J. of Math. 30, 1 (1999), 53-58.

[7] S. S. Dragomir, R. P. Agarwal and P. Cerone, On Simpson's inequality and applications, J. Inequal. Appl. 5, 6 (2000), 533-579.

[8] F. ERTUĞRAL AND M. Z. SARIKAYA, Simpson type integral inequalities for generalized fractional integral, RACSAM 113, 4 (2019), 3115-3124.

[9] L. FEJÉR, Uberdie Fourierreihen, II, Math. Natur. Ungar. AkadWiss. 24 (1906), 369-390, [in Hungarian].

[10] F. Jarad, T. Abdeljawad and D. Baleanu, Caputo-type modification of the Hadamard fractional derivatives, Adv. Differ. Equ. 2012 (2012), 142.

[11] A. A. Kilbas And J. J. TRujillo, Hadamard-type integrals as G-transforms, Integral Transform Spec. Funct. 14, 5 (2003), 413-427.

[12] C. P. LI AND M. CAI, Theory and Numerical Approximations of Fractional Integrals and Derivatives, SIAM, Philadelphia, 2019.

[13] C. P. Li AND Z. Q. LI, Asymptotic behaviors of solution to Caputo-Hadamard fractional partial differential equation with fractional Laplacian, Int. J. Comput. Math. 98, 2 (2021), 305-339.

[14] C. P. Li AND Z. Q. LI, Stability and logarithmic decay of the solution to Hadamard-type fractional differential equation, J. Nonlinear. Sci. 31, 2 (2021), 31.

[15] C. P. Li AND Z. Q. LI, The blow-up and global existence of solution to Caputo-Hadamard fractional partial differential equation with fractional Laplacian, J. Nonlinear. Sci. 31, 5 (2021), 80.

[16] C. P. Li AND F. H. ZENG, Numerical Methods for Fractional Calculus, Chapman and Hall/CRC, Boca Raton, USA, 2015.

[17] C. P. Li, G. Madiha And Z. Q. Li, Finite difference methods for Caputo-Hadamard fractional differential equations, Mediterr. J. Math. 17, 6 (2020), 194. 
[18] G. Madiha, C. P. Li And C. T. Yin, On Caputo-Hadamard fractional differential equations, Int. J. Comput. Math. 97, 7 (2020), 1459-1483.

[19] M. Matolka, Some inequalities of Simpson type for h-convex functions via fractional integrals, Abstr. Appl. Anal. 2015 (2015), 1-5.

[20] K. B. Oldham and J. Spanier, The Fractional Calculus, Academic Press, New York, USA, 1974.

[21] J. PeČARIĆ AND S. VAROŠANEC, A note on Simpson's inequality for functions of bounded variation, Tamkang J. of Math. 31, 3 (2000), 239-242.

[22] J. PEČARIĆ AND S. VAROŠANEC, A note on Simpson's inequality for Lipschitzian functions, Soochow J. Math. 27, 1 (2001), 53-57.

[23] R. Saima, O. A. Ahmet, J. Fahd and A. N. Muhammad, Simpson's type integral inequalities for $\kappa$-fractional integrals and their applications, AIMS Mathematics J. 4, 4 (2019), 1087-1100.

[24] M. Z. SARIKAYA, E. SeT AND M. E. OZdemir, On new inequalities of Simpson's type for $s$-convex functions, Comput. Math. Appl. 60, 8 (2010), 2191-2199.

[25] K. L. Tseng, G. S. YANG And S. S. Dragomir, On weighted Simson type inequalities and applications, J. Math. Inequal. 1, 1 (2007), 13-22.

[26] N. Ujević, New bounds for Simpson's inequality, Tamkang J. Math. 33, 2 (2002), 129-138.

[27] J. R. WANG AND M. FeČKAn, Fractional Hermite-Hadamard Inequalities, De Gruyter, Berlin, Germany, 2018.

[28] G. S. Yang AND H. F. ChU, A note on Simpson's inequality for function of bounded variation, Tamsui Oxford J. Math. Sci. 16, 2 (2000), 229-240.

[29] F. R. Zhang, G. R. Chen, C. P. Li And J. KuRThs, Chaos synchronization in fractional differential systems, Phil. Trans. R. Soc. A 371, 1990 (2013), 20120155. 